Article

\title{
Controversies, Complexities and Contexts: Teaching Islam through Internal Feminist Critique of the Religion
}

\author{
Marianne Hafnor Bøe (iD \\ Department of Cultural Studies and Languages, University of Stavanger, 4036 Stavanger, Norway; \\ marianne.boe@uis.no
}

Received: 13 August 2020; Accepted: 4 December 2020; Published: 9 December 2020

\begin{abstract}
In what ways can teaching Islam through controversial issues be useful in religious education? Can it serve to counter problems of representation of Islam, and what are the benefits and possible pitfalls of adopting such an approach? In this article, I will explore the use of Muslim internal feminist critique of conservative and patriarchal interpretations of women's religious leadership in Islam as a controversial issues approach to teaching Islam in non-confessional religious education. The approach can be relevant for students in upper-secondary religious education, but also in teacher education. Building on secondary research documenting the problems of teaching Islam in non-confessional religious education in the Nordic countries as well as research on Muslim feminism spanning over a decade, this article investigates the didactic potentials and challenges that adopting the controversial issues approach may hold for teaching Islam. The main argument of this article is that the internal feminist debate on Islam provides an alternative entry to teaching Islam. It provides didactic resources and tools for understanding the discursive aspects of Islam, i.e., how Islam is conceived, interpreted, debated and practiced by Muslims, which in turn highlight power aspects and authority that are central to the production of religious knowledge. Consequently, the controversial issues approach may serve to counter certain "grand narratives" that seem to permeate current representations of Islam in religious education.
\end{abstract}

Keywords: Islam; didactics of religion; religious education; controversial issues; study of religions; Muslim feminism; internal religious debate

\section{Introduction}

Recent research has documented comprehensive problems of representation connected to teaching Islam in religious education in the Nordic countries. In short, such problems deal with essentializing and stereotyping Islam, particularly regarding representations of gender issues and internal diversities within the religion (Andreassen 2008; Berglund 2013; Buchardt and Enemark forthcoming; Bøe forthcoming; Härenstam 2009; Otterbeck 2005; Sakaranaho 2019; Sakaranaho and Rissanen forthcoming). There are also studies showing that teaching Islam in religious education in Norwegian upper-secondary schools tends to be influenced by the media's representation of the religion, which in turn enforces stereotypical and conflict-oriented representations of the religion (Toft 2018). Building on such secondary research literature in combination with experiences from researching the topic of Muslim feminism for over a decade, this article explores the didactic potentials and pitfalls that adopting the controversial issues approach, in this case the internal feminist debates of Islam, may hold for teaching Islam in non-confessional religious education.

My starting point in writing this article is in didactics of religion. As a scholar in the study of religions, I have specialized in Islam. In my Ph.D. dissertation, I explored Shia Islamic family law 
and women's rights activism in Iran (Bøe 2015), and I have researched Muslim feminism in a broader international context more recently (Bøe 2019). Over the past couple of years, I have also gained didactic experiences from working in teacher education for religious education in Norway. This article therefore sets out to primarily address didactic tools that can be useful in teaching Islam in upper-secondary religious education, but that also have relevance for teaching Islam in teacher education.

I build on the work of Wanda Alberts, among other scholars in the didactics of religion. Alberts has argued for the need to develop didactics of the study of religions. She claims that pedagogy and educational science alone cannot provide didactic approaches that are suitable for religious education (Alberts 2008). Rather, education about religions in secular frameworks is a direct field of application for the discipline of the study of religions, and can therefore not be thought of separately from the academic study of religions (Alberts 2008, p. 301). Alberts argues further that the analytical and discursive competence that the study of religions provides is needed and can be useful in dealing with religious diversity and questions of representation in religious education (ibid.). In developing didactics of religion, there is also a need to combine the subject knowledge and methodologies of the study of religions with insights from education. Although there clearly are differences between the scope, objective and purpose of the academic study of religions and religious education in schools, they also share certain commonalities related to the critical study of religions in a plural sense. Marking the divisions between the emic and etic, and between the insider and outsider perspectives (McCutcheon 1999), as well as introducing concepts such as lived religion and the world religion paradigm are examples of didactic resources that are significant in both fields (Niemi 2018; Anker 2017). Drawing on such insights in combination with my own expertise in the study of religions, I discuss the potentials and pitfalls that the controversial issues approach holds for teaching Islam. By doing so, I aim to contribute to the development of the didactics of religion and open the repertoire for teaching Islam in religious education.

The article is structured as follows: ${ }^{1}$ first, I will present the controversial issues approach and the didactic potential it can represent in religious education. ${ }^{2}$ I then continue to explore the internal religious debates on Islam, and on women's religious leadership in Islam. I show controversies and complexities that are involved in the Muslim feminist internal critique, and in their debates of women's religious leadership in Islam. In the next section of this article, I highlight key challenges that teaching Islam in non-confessional religious education in the Nordic countries entails. The focus will be on the biased representations that it suffers from, particularly the marginal interest for internal diversity and gendered perspectives on the religion. Considering such challenges, I continue to discuss the didactic potentials and pitfalls that adopting the controversial issues approach, i.e., internal feminist debates on women's religious leadership in Islam, may hold for the representation of internal diversities in Islam, focused on the concept of "binary teaching" (Toft 2019) on the one hand, and on the need to convey critical teachings (Alberts 2008) on the other. The main argument of this article is that teaching Islam through Muslim feminist internal debates of Islam opens for understanding the larger context and power structures existing within the religious tradition of Islam, and portrays diversities within the religion which in turn may counter certain "grand narratives" that permeate current teachings of Islam.

1 I would like to thank the editor of this special issue, Marie von der Lippe, and the anonymous peer reviewers for critically reading the manuscript and suggesting useful feedback.

2 There are different models of teaching Islam in religious education throughout Europe (Franken and Gent forthcoming). The starting point of this article is the teaching of Islam within the framework of an integrative non-confessional model of religious education (Alberts 2007), meaning that Islam is taught as part of a broader course in religion (and sometimes other world views, ethics and philosophy) that is mandatory for all students regardless of their religious affiliation. Such an integrative, non-confessional model of religious education is found in, e.g., Norway, Sweden and Britain. A separative model of religious education, however, means that students are separated based on their own and/or their family's religious affiliation and that they receive religious education accordingly. In the Nordic countries, this latter model is found in Finland. 


\section{What Are Controversial Issues, and How Can They Work as Didactic Tools in Religious Education?}

What counts as a controversial issue in teaching is not a given. Rather, as Marie von der Lippe has convincingly argued, it is a matter depending on context, and on the educational situation, teachers' knowledge, as well as their pedagogical and didactic skills (Von der Lippe 2019, pp. 2-3). Nevertheless, certain topics are more likely to be perceived as contentious than others. According to the Council of Europe (COE), controversial issues tend to arouse "strong feelings and divide opinion in communities and society" (COE 2015, p. 8), and are related to extremism, gender violence, child abuse, or sexual orientation (COE 2015, p. 11). Moreover, it can be understood as: «issues that deeply divide a society, that generate contradictive explanations and solutions based on alternative value systems» (Stradling 1984, p. 121; quoted in Anker and Lippe 2016, p. 263).

For a long time, conflict perspectives were neglected in religious education. In Norway, the general approach in religious education was typically emphatic and understanding, and based on tolerance, respect, and dialogue, and connected to religious and cultural identity (Andreassen 2008, p. 2). Such attitudes were particularly reflected in the religious education curricula and textbooks. Following the increased awareness on the need to adopt a more pluralistic religious education, debates about if and how controversial topics can be raised have emerged (Anker and Lippe 2016, p. 262). Didactically, it has been argued, that the controversial issues approach goes beyond the mere empathetic and essentialist perspectives on religion, and rather engages different analytical perspectives as well as insider and outsider understandings of religion (McCutcheon 1999; Andreassen 2008, p. 18; Iversen 2017; Eidhamar 2019).

Still, teaching religious education using controversial issues can be demanding, academically and pedagogically, for students and teachers alike. It also involves a set of didactic challenges. Lack of time, teachers' competence, and the difficulty of addressing issues outside of the curriculum are commonly reported by religious education teachers in Norway, Britain and the US alike (Anker and Lippe 2016, p. 270). Such difficulties can result in the teachers' reluctance to and avoidance of addressing controversial issues in their teaching (Anker and von der Lippe 2018). Concurrently, studies have found that although teachers feel that addressing such issues are demanding, the students report a strong urge to discuss contentious topics (Quartermaine 2016). In 2015, COE introduced a training pack for teachers on how to deal with controversial issues in the classroom. $\mathrm{COE}$ addressed topics that are considered particularly challenging for teachers, namely teaching styles, classroom climate and control, protecting students' sensitivities, teachers' lack of expert knowledge and dealing with spontaneous questions and remarks (COE 2015, pp. 15-18). In contrast to the COE report, this article does not primarily set out to deal with the practical implementation of how to teach controversial issues in religious education on a general basis. However, it will provide a specific example of what can be addressed as a controversial issue in teaching Islam in religious education and elaborate on the challenges and benefits that this approach entails. It will also suggest how the controversial issues approach can be employed in teaching Islam, by pointing to certain key components that are inherent to the religious knowledge production in Islam. Additionally, this article will elaborate on why teaching a controversial issue, such as women's religious leadership in Islam, is useful in religious education and the benefits exploring internal religious debates within Islam may offer.

\section{The Problem of Gender Equality and "the Woman Question" in Islam}

Questions dealing with gender are not only pertinent to Islam, but increasingly at the core of internal religious debates more generally (Lövheim et al. 2017). Gender is not, however, limited to theological interpretations maintaining conservative or patriarchal gender norms and practices, or feminist internal critique of such theological readings for that matter. Gender issues are also pivotal to identity, how religious people see themselves and how they see their religious tradition as part of the contemporary society. The same goes for Islam. To a larger degree than many other religions, 
however, Islam, but also the presence of Muslims, their practices, and the way some of them dress have emerged as highly contentious issues and sparked massive debates across Europe in recent years. The role of Islam is symptomatically represented as "bad" religion in contrast to (Protestant) Christianity that is depicted as a "good" religion (Abdel-Fadil and Liebmann 2018, p. 286). Moreover, such representations of Islam are highly gendered and play into the othering of Muslims vis-à-vis the majority society. Consequently, issues dealing with gender equality and "the woman question" in Islam has become the most prominent symbol of the cultural and religious encounters and subsequent emerging conflicts (Abdel-Fadil and Liebmann 2018, p. 290). As a result, Islam is commonly seen as contradicting values of gender equality, women's rights, and even notions of "the ideal citizenship" in Scandinavian societies (Abdel-Fadil and Liebmann 2018, pp. 286-89).

Although Islam is often publicly portrayed as a problem for gender equality and women's rights, such depictions of Islam do not necessarily match how most Muslims see their religion. In a large Muslim nations poll conducted by Pew Research Center in 2012, a vast majority of respondents expressed broad support for gender equality (Pew Research Center 2012). On the issue of women's status in economy and in private lives, however, more ambiguous attitudes were expressed (ibid.). Such findings suggest that although the idea of gender equality is embraced at one level, conservative and patriarchal interpretations of gender roles continue to exist among the world's Muslim population and among the majority of religious authorities. Still, there are signs of negotiation and change. A vast majority of Muslims residing in western countries, and particularly that of the younger generation of Muslims, show support of progressive and even feminist interpretations of Islam (Eidhamar 2017; Samani 2016; Ishaq 2017; Synnes 2019). Hence, there are great variations on how Muslims view gender issues, that span from a spectrum of conservative and patriarchal interpretations, to variations of more progressive and feminist readings of the religion.

\section{Internal Debates on Gender within Islam}

The heterogeneity of Muslim views and interpretations is reflected in internal debates on Islam. Although contentious, there is an established tradition for internal religious critique within Islam. Such internal debates involve critical discussions and examinations of religious texts, as well as the legal thinking and reasoning in Islam. Still, such internal debates are often ignored in representations of Islam. The idea that the Quran is the word of God has resulted in a general understanding that the religious sources are undebatable, unchangeable, and not subject to critique (Fazlhashemi 2019, pp. 158-59). One strand of internal critique that has developed within the Islamic religious framework is Muslim feminist thinking. Dealing with issues such as marriage, divorce, sexuality, male guardianship and women's access to religious leadership, Muslim feminist thinking offers a comprehensive alternative to established interpretations, ideas and practices of Islam (Bøe 2019). These are not only issues that are debated from the outside, there is also a long tradition for internal debate within Islam. Discussions of gender, and the status and rights of women have been inherent to debates on Islam's compatibility with modernity. Hence, gender can be seen as a recurrent theme in conservative and progressive discourses on Islam alike.

Although often framed as controversial and sometimes even as taboo from the outside, the internal feminist critique provides in-depth insights and understandings of how gender issues are debated to a great extent within the religion. Moreover, it adds information on the method of internal religious critique existing within Islam. In the following, I will show some of the nuances and variations in internal feminist critique of conservative and patriarchal interpretations of Islam, before I continue to discuss the potentials and pitfalls that this topic may represent in teaching Islam in the next sections of this article.

\subsection{Internal Feminist Debates on Islam}

Muslim feminist theological debates on how to understand gender issues in the Quran, the hadith literature and in Islamic jurisprudence (figh) are widespread and comprehensive. Going back to at least 
the late 1800s, the Muslim feminist discourse constitutes different strands of religious thought and interpretations. At present, Amina Wadud is one of the most renowned scholars in the field. Wadud is an American Muslim who currently resides in Indonesia and is a founding member of the Muslim women's movement Sisters in Islam. Wadud is author of the book Quran and Woman (Wadud 1992); the first feminist interpretation of the Quran in modern times. She has training in Islamic studies and Arabic and has focused on what she refers to as "gender jihad", a progressive fight for including radical gender justice within Islam (Wadud 2006). By doing so she has sparked debate on whether a woman has leadership authority in Islam and promoted a radical form of Muslim feminism that opens for the full equality between men and women, inclusion of LGBTQ+ persons and women as imams.

Pakistani-American Asma Barlas and American Kecia Ali are other prominent examples for feminist tafsir (Quranic exegesis). Although they each represent distinct approaches, they have both published books that present feminist readings of the Quran and the Sunnah (i.e., the sayings and practices of the Prophet Muhammad) (Barlas 2002; Ali 2006). There are also other representatives of the contemporary Muslim feminist discourse that are not primarily occupied with textual sources and interpretations. British-Iranian Ziba Mir-Hosseini has focused on Muslim family law reform and criticizes gender discriminatory practices that are being legitimized in the name of Islam. Mir-Hosseini is also known as a founding member of the organization Musawah, Global Movement for Equality and Justice in Muslim Family. Her mission has been "to decode the patriarchal DNA of Muslim family laws" (Mir-Hosseini 2012), to which the deconstruction of patriarchal readings of the Quran and the Islamic jurisprudence (usul al-figh) are central. South-African Sadiyya Shaikh has examined gender perspectives within the Sufi tradition of Islam (Shaikh 2012), and Moroccan Asma Lamrabet has questioned the legitimacy for stoning as punishment for adultery, as well as the ban against intrareligious marriages with reference to her feminist reading of the Quran (Lamrabet 2016). Egyptian Mona Eltahawy rejects notions of shame and honour connected to Muslim women and has advocated for a sexual revolution in Islam (Eltahawy 2015). Turkish-German Seyran Ateş is known as the founder of the inclusive Ibn Rush Goethe mosque in Berlin, where gender-mixed prayers, same-sex and intrareligious marriages are conducted (Bøe 2019, pp. 110-12). These examples offer a glimpse into the breadth of the contemporary Muslim feminist discourse, and a further look into the Muslim feminist theological debate on gendered and inclusive leadership in Islam can illustrate some of the arguments, methods and sources that are involved in the feminist internal critique of conservative and patriarchal readings of Islam.

\subsection{Women's Religious Leadership in Islam}

What kind of religious leadership roles can a woman hold in Islam? Can she act an imam and lead prayer? Can she function as a religious scholar (alim), or serve other important religious functions in Islam? These questions have provoked debate across Muslim communities internationally in recent years (Bøe 2019, pp. 94-97). Although the idea that religious and political leadership in Islam remains reserved for men is supported by most Muslim communities worldwide, it is also increasingly being challenged. Muslim feminists are among those who have disputed conservative and patriarchal readings of the Quran and Sunnah on the issue (see e.g., Wadud 1992; Barlas 2002; Lamrabet 2016). Instead of seeing religious leadership as reserved for men only, they argue that the Quran and Sunnah pave way for justice as a guiding principle for the relationship between gender. As a result, Muslim feminists open for more gender inclusive understanding of religious leadership.

The late Fatima Mernissi (1940-2015) conducted a feminist critical reading of the hadith literature and questioned the religious legitimacy of the hadith that have become evidence that women cannot hold leadership roles within the religion (Mernissi 1991). Religious interpretations that exclude women from leadership positions are partly based on a hadith from al-Bukhari's collection, dedicating the following quote to the prophet Muhammad: "Never will succeed such a nation as makes a woman their ruler" (al-Bukhari n.d.). al-Bukhari's hadith is considered sahih (authentic), and the statement has been seen as a general ban against women's leadership. 
Mernissi, however, challenged this understanding and argued that there is no basis for such a ban in the religious sources. In the book The veil and the Male Elite, published in 1987, Mernissi investigated the statement behind the hadith. Through a critical examination of not only the origins of the hadith, but also the chain of human transmitters behind the statement, she claimed that there is no basis for a general and universal ban on women's leadership.

The intent here is not to argue that that Mernissi's interpretation, or that of any other Muslim feminist, is more or less correct than the ones offered by conservative and patriarchal understandings of the issue. Rather, the purpose is to situate Muslim feminist interpretations within Islam, and to show that they draw on sources and approaches that are embodied in the Islamic interpretative tradition. Mernissi's approach involves a critical reading of the accounts that are available from the early history of Islam, such as the Prophet's Sunnah. The historical contextualization approach is also applied in Quranic interpretations, meaning that the Quran is understood considering the time and situation it is said to be revealed. This approach is not only central to Muslim feminist methodology, but to classical tafsir at large.

When applied to hadiths, it involves a critical assessment of the chain of transmitters of stories about the sayings and practices of the Prophet, what is referred to as isnad in Arabic. This source criticism is pivotal for the authorization of a hadith, and serves as basis for any hadith to qualify as authentic (sahih), good (hasan) or week (daif). When used for Quranic exegesis, the approach builds on a basic divide between the descriptive and the prescriptive verses in the Quran, i.e., verses that describe the practice in the Arabic peninsula during the 5th century, and verses that prescribe practices that hold general validity. A further divide is between verses that are relevant for specific situations, and those considered to have universal significance. Additionally, historical events that could have had an impact on certain revelations are identified (Hidayatullah 2014, pp. 65-66). In classic tafsir the historical contextualization approach has resulted in a larger collection of texts that interpret Quranic verses in the historical situation of the presumed revelation, so-called sabab al-nuzul. Collections of asbab al-nuzul (plural of sabab al-nuzul) have also been used to gain a more precise understanding of what a verse means, and what kind of validity one Quranic verse may have compared to another (Donner 2010, p. 30). The historical contextualization approach not only informs religious understandings and interpretations of the Islamic sources, but also supply a basis for ongoing feminist debates on religious leadership in Islam.

\subsection{Can a Woman Serve as an Imam?}

A substantial proportion of the debate on women's religious leadership in Islam has revolved around the role of the imam. The Arabic word imam translates into "leader" or "the one who stands in front". Although the term may hold different meanings and the imam may serve different functions and tasks, it most commonly refers to the person leading the prayer and delivering the $k h u t b a$ (sermon) during the Friday service in a mosque. ${ }^{3}$ As to having women serve as prayer leaders, three interconnected questions arise: Can a woman lead prayer, who can they lead, and what kind of prayers can they lead? (Hammer 2012, pp. 83-84). Legal decisions on these issues have varied within the different schools of law (madhahib). Most commonly, the Hanbali and Shafi'i schools of law acknowledge that women can lead other women in prayer under certain circumstances and for certain prayers (ibid.). However, having women as imams in front of gender-mixed congregations are much more controversial, and none of the established schools of law acknowledge women in such leadership roles (Bøe 2019, p. 95). A widespread understanding builds on the idea that only men can stand in front of other men, and that it is not decent for women to be in the position in front of men (Bøe 2019, p. 95).

3 Within Shia Islamic traditions, the term imam constitutes a distinctive doctrine on who can serve as legitimate spiritual and political successors to the Prophet Muhammad. The doctrine of the imamate moreover differs according to the different branches of the Shia tradition. 
The question of religious leadership is thus linked to issues of modesty and temptation, which again has been used to legitimize gender segregation in mosques and other arenas (Hammer 2012, p. 84).

Nonetheless, there are several cases where women have functioned as imams. In China, women have been imams for other women in women-only mosques in China (so-called nüsi) since the early 1800s. Additionally, there are women-only mosques established more recently in Amsterdam, and in Copenhagen, where the Maryam mosque was initiated in 2016. Although the Maryam mosque is open for all on weekdays, the Friday service is exclusive for women.

The establishment of so-called inclusive mosques have been a concurrent initiative to women-only mosques. The Inclusive Mosque Initiative (IMI) was first launched in London in 2012. ${ }^{4}$ IMI promotes intersectionality in combination with Islam, and sees no sectarian, political, or ethnic divisions in who can enter and take part in a mosque, nor does it discriminate based on functional abilities, according to the IMI website. ${ }^{5}$ The IMI also promotes inclusive participation regardless of gender and sexual identities and orientations. The project was initiated as a reaction to the experience that many Muslim women had in British mosques. Discontent with being moved to dark, small rooms often dislocated from the main room of the mosque, that moreover often lacked proper access to the khutba, IMI set up alternative mosques that opened for the inclusive participation of Muslims (Bøe 2019, p. 105).

The IMI project has inspired similar initiatives in North America, as well as in several European countries. The Ibn Rushd Goethe mosque in Berlin, Germany, was founded in 2017, and advocates an "inclusive and progressive Islam". 6 The mosque is not only open for gender-mixed prayers, but also has women and LGBTQ+ persons as imams who perform same-sex and interreligious marriages. The Fatima mosque was initiated as yet another inclusive mosque project in Paris, France, in 2018, ${ }^{7}$ where Kahina Bahloul functions as the main imam and has served gender-mixed prayers. Further, in Oslo, there have been attempts to establish an inclusive mosque in recent years. The organization Salam is behind the initiative. ${ }^{8}$ Working primarily for the inclusion of LGBTQ+ Muslims, it organizes monthly prayers sessions at present without any permanent location or an imam "in residence".

\subsection{Internal Debate on Women's Religious Leadership Also among Muslim Feminists}

Women's religious leadership, and particularly that of having women imams, is a contentious issue within Islamic schools of law and in Muslim communities. However, it is subject to theological debate also among Muslim feminists who present dissimilar understandings of the issue. On one end of the scale, we find Amina Wadud. In 2005, she publicly announced that she would lead prayer and deliver a khutba in front of a gender-mixed congregation in New York, USA. This was not, however, her first imam performance. She had already been involved in similar events in Cape Town in 1994, in Barcelona in 2005, and in Oxford in 2008, in addition to several smaller and unannounced events in the US and in Indonesia. However, not all Muslim feminists agree with Wadud's stance on women's religious leadership. Sherin Khankan represents a different approach. As mentioned earlier, she was initiator behind the Maryam mosque in Copenhagen in 2016, where she also serves as imam. Unlike Wadud, however, Khankhan has avoided the role of imam for gender-mixed assemblies. Considering the contentious character of the issue, she has been open on her acting as a woman-only imam as a pragmatic choice. A third alternative can be found in Halima Krausen's approach to women's religious leadership in Islam. Krausen inherited the position as imam at the Imam Ali mosque in Hamburg when her predecessor retired, and when active in the role she led prayer for women-only as well as gender-mixed groups (Petersen 2019, p. 5). Although she has stressed the need for having women performing the khutbah and functioning as prayer leaders, she has nonetheless been reluctant to claim

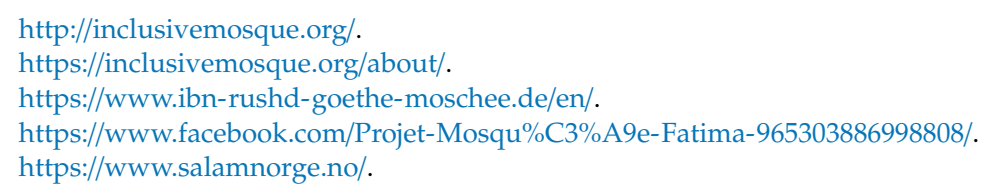


the imam title herself (ibid.). A similar reluctance in claiming the imam title can be found also in the debate on women's religious leadership in Norway. In Norway, Rania Jalal al-Nahi has advocated the need to have women in leadership roles in mosques. Although she has been hesitant to adopt the imam title, she has used the term "mosque leader" and underlined the need to have a woman's perspective on cases dealing with divorce and family therapy and counseling. Some Muslim feminists emphasize the importance of such tasks for women's Islamic religious leadership over that of adopting the imam title.

American Ingrid Mattson represents a fourth approach to the issue of women's religious leadership. Mattson has argued in favor of having women in leadership positions. However, she rejects that women should serve as imams. She claims that women's religious leadership is conditioned. As she sees it, a woman can lead the prayer in her own household, if she is the most qualified person present for undertaking the task (Mattson 2005). Still, she underlines that there is wide agreement that women should not lead men in prayer. She refers to hadiths stating that Muhammad encouraged women to pray behind men, and to avoid the gaze of men during prayer. Mattson moreover accuses other Muslim feminists of being too preoccupied with claiming women as imams. She is rather concerned with promoting women in other religious leadership roles that she considers to be of larger importance, than leading prayers. Mattson stresses that women should gain religious knowledge and authority, and advocates for women to become ulama, Islamic scholars. Having an influential woman as alima (i.e., the singular and feminine form of ulama) would, according to Mattson, have far more impact on religious knowledge production, than simply having women leading prayers as imams (Bøe 2019, pp. 98-99).

The ambivalence towards the imam title reveals some of the complex structures of authority that are connected to Islamic leadership roles. Although all the above-mentioned approaches present internal critique of established views on who can hold religious leadership in Islam, there are still some significant differences to be found. When Amina Wadud leads prayer and delivers the khutba in front of gender-mixed groups, she represents a clear break with the established view on who can stand in front and hold such leadership positions. Khankan, however, adopts a more pragmatic approach. Acting as a woman-only imam, she positions herself within the broadly accepted terms for women's religious leadership. Still, she challenges the established view, by offering an alternative approach. Whereas Krausen and al-Nahi place themselves somewhere in-between, Mattson's approach is in line with more conservative readings that excludes women from acting as imams. However, she joins a series of initiatives to enhance women's religious scholarship and authority in other positions and arenas in Iran, Nigeria, Indonesia, and Morocco in recent years (Ahmed 2016; Bano and Kalmbach 2012; Van Door-Hardner 2006; Rinaldo 2013; Kian-Thiébaut 2000). In some cases, such initiatives seek to open for women's broader religious authority and leadership, while in other cases they look to relegate women to separate fields of religious authority only relevant for women. The different approaches to women's religious leadership in Islam, also portrays the importance of context in such discussions. As Jesper Petersen suggests, the various approaches illustrate how the word imam can change meaning depending on context. He writes: "(.. ) in one setting it [the word imam] is a respectful address whereas in another setting it is a claim to religious authority or maybe even a challenge to the structure of religious authority" (Petersen 2019, pp. 5-6). Moreover, the debate in itself shows that what counts as controversial is highly contextual. Whereas the issue of women's religious leadership is hardly addressed in certain conservative Muslim contexts, it has become a recurrent topic of debate among more progressive Muslim communities.

The purpose of this article is not to elaborate on the complexities of the feminist and progressive branch of Muslim thought, but to show some aspects of Muslim feminist religious thinking and reasoning. The Muslim feminist debate not only challenges the idea of the gender question as a "settled" issue within Islam, but moreover illustrates the premises for internal religious debates. The historical-contextualization approach focusing on the "occasion of revelation" (asbab al-nuzul), and the source-critical approach inherent to hadiths highlight the discursive aspects of Islam, and bring 
to the fore processes of change and variability that are central to Islam. The internal feminist debate on women's religious leadership also sheds light on the complexity of religious authority that are pivotal to the production of Islamic knowledge. Although the different understandings and interpretations of religious texts and practices rely on a set of shared foundations and methods, they are also highly dependent on context. Which interpretation will gain ground and be endorsed remains a question of religious legitimacy that again can be dependent on a number of external factors, such as gender, class, educational background, geography and religious proximity. For the time being, however, let us return to the didactic issues at stake in teaching Islam.

\section{Standard Representations of Islam in Religious Education}

Although there are wide variations in how Muslims perceive gender issues and on the topic of gender equality, such nuances tend to be ignored in how Islam is represented in religious education. Through a case study observation in a religious education classroom in a Norwegian upper-secondary school, Audun Toft examined the widespread use of media in teaching Islam, and the impact it had on the teacher's didactic choices, planning and teaching (Toft 2018). Although the influence of media was multifaceted, a key finding in the study was that the recurrent use of media functioned as a gateway for teaching Islam, with the result that the religion was associated with the portrayal established by the media, linking Islam to terrorism, conflict and controversy (Toft 2018). As a result, discussions on gender typically included cases from Saudia Arabia, Iran, Taliban and IS, as well as questions dealing with the possible oppression of Norwegian Muslim women (Toft 2018, p. 274).

Generally, there seems to be a marginal interest in the teaching of Islam in religious education in the Nordic countries (Bøe forthcoming). Gendered perspectives tend only to be anecdotally mentioned, either as an overall fundamental societal value, or through teaching goals dealing with gender and sexuality more generally (Andreassen forthcoming; Berglund forthcoming; Buchardt and Enemark forthcoming). If gender perspectives are included, they often build on biased representations of Islam. In a study of how Swedish textbooks portray Islam, Kjell Härenstam found that Islam was portrayed as a patriarchal and oppressive religion, and that gender was seen through the standard lens of "the oppressed Muslim woman". Shari'a was associated merely with hudud penalties, whereas the everyday Shari'a practices such as daily prayers and halal food regulations were ignored. The fact that the latter aspects of Shari'a are what most Swedish Muslims relate to, and that hudud represents a marginal aspect of Shari'a for the vast majority of Swedish Muslims, were not reflected in the textbooks. Härenstam maintains that such representations of Islam were not necessarily erroneous. Rather it was the choice of "facts" identified with the religion that were distorted (Härenstam 2009). The ways in which "ordinary" Muslims debate and negotiate such issues, were nonetheless ignored. Such non-critical representations of Islam in turn risk excluding the great span of opinions on the issue. However, to approach the gender question as a "settled" issue in Islam, does not only impact the image of Muslim women. Those who fall outside of heteronormative gender roles and norms, e.g., LGBTQ+ persons, are also further marginalized in such representations of Islam. Still, the lack of addressing diversities reflecting gender are certainly not only limited to religious education. Androcentrism, in combination with ethnocentric and hegemonic approaches have informed the broader academic study of religions, and in certain areas also continue within the discipline (Joy 2001; Alberts 2007; Sky 2007; Bøe and Kalvig 2020).

Another problem of representation of Islam in religious education relates to Sunni Islam being presented as the default version of Islam, whereas other diversities within the religion are regularly overlooked (Bøe forthcoming). Portraying such "default versions of Islam", fails to encompass internal diversities and debates existing within Islam, in a similar way to that of approaching gender issues in Islam as undebated and as "settled". In Finland, for instance, there are several curricula dedicated to the education of Christianity (e.g., Lutheranism; Orthodox Christianity; Catholicism), but only one for Islam (Sakaranaho and Rissanen forthcoming). As a result, "general Islam" and the unity of all Muslims are promoted, but at the stake of other Muslim minorities such as Shia, Ibadi, Ahmadiyya, 
Tatar Muslims, etc. A related study from Finland also shows that some religious education teachers favor the teaching of "general Islam" in schools as a way of promoting the unity of Finnish Muslims, leading some parents and students to question the teachers' ability to represent the diversity of Islam in an impartial manner (Rissanen 2012). These examples underline the need to adopt alternative approaches in teaching that can pave way for more nuanced and pluralistic perspectives on Islam in religious education.

\subsection{Didactic Challenges in Teaching Islam}

The widespread influence of the media on teaching Islam pose a set of didactic challenges. According to Audun Toft, the adoption of the polarized structure of media debates in teaching Islam in Norwegian upper-secondary schools, led the more extreme actors within the religion to be privileged in teaching (Toft 2019). Although opposing views are portrayed to offer more nuanced representations of Islam, the most controversial view still received the most attention. As a result, the teaching focuses on the same issues that the teaching sets out to counter, namely extremism and terrorism. Hence, the controversial issues that are prominent in the media coverage of Islam, not only set the scene for teaching Islam in religious education but also reinforce "the 'normality' of extremism in Islam" (Toft 2019, p. 325). Toft refers to this phenomenon as "binary teaching" (Toft 2019, p. 326). The term points to the polarization involved in teaching Islam, i.e., focusing on two parties with different views. The main problem seems to be that the two parties receive different forms of identification. Whereas one party is identified by the traits they hold ("positive identification"), the other is identified by what they are not ("negative identification") (Toft 2019, p. 334). The result is a form of binary teaching that favors knowledge about the party that has been positively identified. The other party, however, is "empty of content" (Toft 2019, p. 334). Toft elaborates:

"As in the lesson analysed above, the ordinary Muslim women given voice in the lesson teach us that the extremists maintain that it is mandatory for women to wear the hijab, and homosexuality, apostasy, premarital sex and blasphemy warrant the death penalty. These views are expanded on during the lesson. Presumably, the three women hold opinions and advocate certain Muslim practices; these, however, are rendered irrelevant by the polarization structure. They do not belong within this particular context". (Toft 2019, p. 334)

A recurrent problem in the lessons analyzed by Toft is not connected to the controversial character of the topics introduced in the teaching, such as hijab, gender inequality or LGBTQ+ topics. However, the main issue seems to be intrinsically linked to the lack of context added to the topics addressed. The teaching tends to focus on the opinions held by the extremist views, while the opinions of the "ordinary" Muslims are not included. The lack of contextualization of views held by ordinary Muslims not only risk ignoring variations of "lived" and vernacular Islam connected to how Muslims practice and conceive of their religion, and that can be ambivalent and contradictory (Schielke and Debevec 2012). It moreover ignores the power issues involved in religious interpretations, as well as a broader understanding of the discursive structures that are recurrent in internal debates on Islam.

The lack of attention towards power aspects in representations of Islam is a didactic challenge connected to teaching Islam, raised by Jonas Otterbeck (2005). Otterbeck conducted a survey on textbooks used in Swedish upper-secondary schools' religious education. He found that representations of Islam lacked an understanding of power practices, making it impossible for the reader to understand whose interpretation of Islam is given, or how widespread that specific interpretation is within the religious tradition at large (Otterbeck 2005, pp. 802-3). Furthermore, Otterbeck found that Islam was frequently "othered", both in the well-discussed fashion of Orientalism and with Islamist interpretation as representative of Islam (Otterbeck 2005, p. 798). On this basis, Otterbeck claims that the textbooks do not include reflections on power practices behind an interpretation. He writes:

“Questions such as 'who interprets?' and 'Who's interpretation am I promoting?' cannot have been asked during the writing process. Islam is an abstraction encompassing different 
theological interpretations and lived experiences. By simply using 'Islam' as a subject, all this diversity is done away with (... ) Sex, class and differences in interpretation barely get a mention, to the obvious benefit of men-who become the norm-and the Islamist theologians-who are given priority over other interpreters of Islam" (Otterbeck 2005, p. 808).

The didactic challenges elevated by Toft and Otterbeck are recurrent in religious education, and in teaching Islam in particular, and the lack of attention towards power issues and contextualization comes forward as a main challenge in teachings of Islam. Arguably, there is a need to adopt didactic tools and resources that can facilitate the understanding of the heterogeneity of Muslim practices and interpretations as expressions of Islam.

\subsection{Teaching Islam as a Discursive Tradition}

A main problem for the representations of Islam in teaching revolves around encompassing the heterogeneity of Muslim practices and interpretations as expressions of Islam. To address a pertinent issue in this article: In teaching, how can we, from a secular and non-confessional starting point, approach religious diversities as represented by both conservative and patriarchal practices and interpretations and the ones offered by Muslim feminists as expressions of the same religion, and as part of Islam?

In order to answer this question, it can be useful to confer how such issues have been dealt with in the academic study of Islam. Talal Asad criticizes the attempt to resolve the problem of diversity within Islam by adapting to a polarized distinction between orthodox or non-orthodox Islam (Asad 2009, p. 8); a sort of division between ulama and Shari'a law in the cities vs. saints and variable customs among the tribes (Asad 2009, p. 9). ${ }^{9}$ From a scholarly perspective, neither can claim to be "more real" or "more correct" than the other. Departing from such approaches, Asad suggests that Islam is best understood and studied through the concept of a "discursive tradition" (Asad 2009). He writes:

"If one wants to write an anthropology of Islam one should begin, as Muslims do, from the concept of a discursive tradition that includes and relates itself to the founding texts of the Qur'an and the Hadith. Islam is neither a distinctive social structure nor a heterogeneous collection of beliefs, artifacts, customs, and morals. It is a tradition". (Asad 2009, p. 20)

Asad's approach has proven not only relevant for an anthropology of Islam, but across several disciplines, including the study of religions. To understand Islam as a discursive tradition also has potential for teaching Islam in religious education.

A main challenge connected to teaching Islam does not only rely on the problems of representing diversity and differences of opinion within Islam more generally. As shown by Toft and Otterbeck's research, it moreover entails the lack of attention towards context and power issues that are inherent to the religion. Approaching Islam as a discursive tradition can serve to counter these shortcomings. A tradition, according to Asad, consists of discourses that instruct practitioners on the "correct form and purpose" of a given practice (Asad 2009, p. 20). Such discourses are not, however, random, or inconsistent. Rather, they refer to a past and a future, through a present. As a discursive tradition, Islam points to the ways in which Muslims discuss and interpret their religion with reference to these frameworks. Thus, Asad's main argument is that one cannot understand or study Islam without taking the full tradition of Muslim discourses into account; they convey conceptions of the Islamic past and future, and at the same time reference "a particular Islamic practice in the present" (Asad 2009, p. 20).

The didactic potential of adopting the discursive approach towards Islam in religious education involves paying attention to the power structures of the religion, in ways that can elaborate on how the social conditions of such a tradition are created, maintained, and potentially changed. Although Islam

9 Asad's paper was first published for the Occasional Paper Series at Georgetown University in 1986, and later reprinted by the journal Qui Parle by Duke University in 2009. 
as a discursive tradition is not homogenous, it aspires to coherence in a way that all discursive traditions do (Asad 2009, p. 23). It is exactly this strive towards coherence that signifies the conditions for knowledge production and power structures that are at play in the internal debates on women's religious leadership in Islam revised in this article. The Muslim feminist debate on women's religious leadership offers insights into the discursive structures of Islam. It relies heavily on the Quran and the Sunnah, as well as the recognized rules and procedures for offering religious critique. It is not a matter of "anything goes" approach. Rather, the internal feminist critique on Islam signify the discursive structures and power relations that are inherent to the religious traditions in study.

I would also argue that the Muslim feminist discourse portrays ways in which established versions of Islam are challenged and potentially can change. Muslim feminist interpretations of Islam privilege non-patriarchal and progressive readings of gendered issues within the religion. The endorsement they receive for their alternative views depends on who is asked and on the broader situation in which they operate. It moreover relies on which version of the Muslim feminist discourse is presented. As seen in the previous sections, there are quite extensive differences of opinion among Muslim feminists on the issue of women's access to religious leadership within Islam. Whereas the more radical voices call for the ability of women and even any LGBTQ+ person to act as imam for a gender-mixed assembly, there are also those who acknowledge that women should seek religious leadership in other roles. Additionally, there is a spectre in-between these two extremes. The point being is that although the different versions of Muslim feminist critique refer to the broader tradition of Islam, the different and alternative versions signify complexities existing within the same discursive tradition. Such complexities may prove valuable for obtaining a pluralistic religious education, and for teaching controversial issues within Islam in particular. As such, the feminist internal debate on Islam can provide resources for teaching Islam in religious education.

\subsection{Countering Grand Narratives on Gender and Islam}

At the onset of this article, I introduced Wanda Alberts ideas for developing didactics for the study of religion. As Alberts suggests, we need to look to the academic and critical study of religions to find suitable solutions for the challenges of representation and the issues of religious plurality within religious education. Wanda Alberts has long contended for the need to acknowledge postmodern, postcolonial, and feminist critique in integrative religious education (Alberts 2008, pp. 318-19). Such critical approaches to religion, can function as entrances and corrections to the problems of representation that is inherent to religious education, she argues. By addressing problems concerning the "conscious or unconscious reproduction of grand narratives» in religious education, the student may themselves make up their own minds about the so-called "standard versions" and "grand narratives" of each religion (Alberts 2008, pp. 318-19). The problem of gender equality and "the woman question" in Islam comes forward as central to current grand narratives within Islam, and Muslim feminist internal critique may serve to expound the diversity of opinions and interpretations of the issues. To succeed, the teacher will need certain didactic tools that can help organize and structure the heterogenic practices and interpretations introduced in teaching. One approach that could prove useful in this regard is Robert Jackson's interpretative approach to religious education (Jackson 2019). Jackson himself draws heavily on the discipline of anthropology in developing the interpretative approach as a didactic tool for understanding religious practices and languages. In short, the approach consists of three key ideas: representation, interpretation, and reflexivity. For the purpose of this article, the former idea of representation is highly relevant. To counter homogenous representations of religions, Jacksons focuses on three levels of representation, i.e., the individual, the group and the broad level of tradition (Jackson 2019, p. 18). Distinguishing between these three levels, and at the same time addressing the interplay between them, can serve to illustrate the complexity of representing religions, and elaborate on the ways in which individual and perhaps "lived" religion relate to and fit into particular groups and broader traditions (Jackson 2019, p. 18). It can also prove useful to situate 
different theological interpretations within the same discursive tradition, e.g., placing Muslim feminist discourses within internal debates on Islam.

We can also turn to the academic study of religion to find didactic tools that can help sort out issues of representations. The questions posed in Bruce Lincoln's seminal text "These on Method" can prove useful also for representing various narratives in Islam in religious education. Lincoln asks:

"Who speaks here?", i.e., what person, group, or institution is responsible for a text, whatever its putative or apparent author. Beyond that, "To what audience? In what immediate and broader context? Through what system of mediations? With what interests?" And further, "Of what would the speaker(s) persuade the audience? What are the consequences if this project of persuasion should happen to succeed? Who wins what, and how much? Who, conversely, loses?". (Lincoln 1996, p. 225)

Asking these questions can serve as didactic tools when teaching Islam through Muslim feminist discourses. Arguably, they will help to discern not only between patriarchal and feminist versions of the religion, but moreover open for the recognition of internal differences and controversies existing within different strands of religious thinking. Lincoln points to the role of the speaker, the audience, and generally underlines the interests and consequences that are at stake. As such, he offers an alternative entrance into discerning power relations and the contextuality of such matters. Debates that have marginal importance or are even considered to be highly controversial in some contexts, can prove to be fundamental and necessary in others. In the case of women's religious leadership within Islam, such debates can prove pertinent in religious education in the Nordic countries, where gender equality and inclusion are recognized as core values in society and in education. This is not the case everywhere, and the societal context will impact both the relevance and the contentious character of debates on women's religious leadership.

Adopting controversial issues in teaching Islam in religious education is moreover highly dependent on the classroom. One objection could be that introducing feminist interpretations of Islam could provoke debate and that it could be challenging to protect students' sensitivities and the classroom climate in dealing with such issues. Such cases could prove highly demanding and require pedagogic competence and in-depth knowledge on Islam that not all teachers may possess. At the same time, it could be argued that addressing controversial issues such as gender norms and internal differences within Islam has the potential to provoke debates and provocations in certain classrooms. It could even offer a possible solution on how to navigate pluralistic classrooms. Lars Laird Iversen has suggested that instead of thinking of the classroom as "safe space" that exclusively share common values, he recommends an alternative concept and approach, i.e., "construing the RE classroom as a community of disagreement (Iversen 2019, p. 315). Rather than seeing disagreement as a threat, Iversen holds that acknowledging disagreements will instead facilitate and encourage a religious education that promotes participation, rethinking and freedom of speech in a religious pluralistic society (Iversen 2017, p. 101). The ability to consider religious traditions as communities of disagreements, such as Islam or Christianity for that matter, will enable the students a thorough and relevant understanding of the religion in question, according to Iversen, one in which the internal diversity of religious traditions is taken seriously. It could also be key to acknowledging classroom disagreements and trigger necessary debate on disputed issues in a pluralistic classroom. Hence, community of disagreement could serve as a tool for obtaining a more pluralistic religious education, and for teaching controversial issues within Islam in particular.

Do all teachers possess the in-depth knowledge on Islam required in order to introduce such controversial issues to their students? Not necessarily. Clearly, the level of complexity that is introduced to the students must depend on the teachers' as well as the students' capabilities. Still, as the problem of gender equality and "the woman question" in Islam pervades most representations of the religion in one way or another, there is good possibility to find feminist internal critique that is suitable, manageable and accessible for students and teachers alike in the religious education classroom. Internal feminist critique of Islam could serve as both a fruitful topic of debate and as an eye-opener 
on how many students perceive Islam. In the previous, I have elaborated on one such case that could prove suitable for both these purposes.

\section{Controversies, Complexities and Contexts}

The main question in this article has been to inquire the potentials and pitfalls of deploying controversial issues in teaching Islam in religious education. At present, teaching Islam suffers from a conflict-oriented approach, that tends to lead to binary teaching and ignore power issues and contextuality. To counter such problems, I have suggested to delve into an ongoing theological debate in the religion, and discussions on women's leadership in Islam in particular. The Muslim feminist discourse offers an alternative gateway into a contentious issue, which is also subject to both external and internal religious critique. The internal feminist debate on the issue can serve to counter existing "grand narratives" on gender that are privileged in representations of the religion. Adopting the controversial issues approach in teaching Islam can be demanding for students and teachers alike. However, it could also represent a timely break with the same old, standard versions that tend to permeate the teaching of Islam in religious education classrooms.

The main purpose of employing the controversial issues approach, illustrated here through the feminist internal critique of Islam, is that it adds information on internal religious debates that are predominant in Islam and supply insights into how gender issues are debated to a great extent within the religion. Teaching Islam through feminist internal critique of the religion has the potential to introduce a more processual, contextual, and critical approach to Islam in religious education. It provides didactic resources and tools for understanding the discursive aspects of Islam, mainly on how the religious sources are criticized, examined and interpreted. Focusing on Muslim feminist internal critique also opens for a discussion on power aspects and authority in Islam, and in turn who has the legitimacy to speak on behalf of the religion.

Funding: This research received no external funding.

Conflicts of Interest: The author declares no conflict of interest.

\section{References}

Abdel-Fadil, Mona, and Louise Liebmann. 2018. Gender, Diversity and Mediatized Conflicts of Religion: Lessons from Scandinavian Case Studies. In Contesting Religion. The Media Dynamics of Cultural Conflicts in Scandinavia. Edited by Knut Lundby. Berlin/Boston: De Gruyter, pp. 281-98.

Ahmed, Sumayya. 2016. Learned Women: Three Generations of Female Islamic Scholarship in Morocco. The Journal of North African Studies 21: 471-72. [CrossRef]

Alberts, Wanda. 2007. Integrative Religious Education in Europe: A Study-of-Religions Approach. Berlin: Walter de Gruyter. Alberts, Wanda. 2008. Didactics of the Study of Religion. Numen 55: 300-34. [CrossRef]

al-Bukhari, Muhammad. n.d. «Hadith no. 219». In Sahih Bukhari. Makkah: Dar Ul-Hadith, vol. 9, bok 88. Available online: https://www.sahih-bukhari.com/Pages/Bukhari_9_88.php (accessed on 8 December 2020).

Ali, Kecia. 2006. Sexual Ethics and Islam: Feminist Reflections on Qur'an, Hadith and Jurisprudence. Oxford: Oneworld Publications.

Andreassen, Bengt-Ove. 2008. Konfliktperspektiver i religionsundervisning og religionsdidaktikk: En bredere og bedre tilnærming til religion? Acta Didactica 2: 1-22. [CrossRef]

Andreassen, Bengt-Ove. forthcoming. Islam in Norwegian RE. In Islamic Religious Education across Europe. Edited by Leni Franken and Bill Gent. New York/London: Routledge.

Anker, Trine. 2017. På tide å si farvel til verdensreligionsmodellen? In Religion i Skolen: Didaktiske Perspektiver på religions-og Livssynsfaget. Edited by Marie von der Lippe and Sissel Undheim. Oslo: Universitetsforlaget, pp. 25-34.

Anker, Trine, and Marie von der Lippe. 2016. Tid for terror: Læreres håndtering av kontroversielle spørsmål i skolens religions-og livssynsundervisning. Prismet 67: 261-72. [CrossRef] 
Anker, Trine, and Marie von der Lippe. 2018. Coming to Terms with Terrorism? A Case Study on how Schools are Dealing with the Terror Attacks of 22 July in Oslo and at Utøya. In Religion and Dialogue in the City. Case Studies on Interreligious Encounter in Urban Community and Education. Edited by Marie von der Lippe, Thortsen Knauth, Anne Körs, Julia Ipgrave and Dörthe Vieregge. Münster/New York: Waxmann Verlag, pp. 247-61.

Asad, Talal. 2009. The Idea of an Anthropology of Islam. Qui Parle 17: 1-30. [CrossRef]

Bano, Masooda, and Hilary Kalmbach, eds. 2012. Women, Leadership and Mosques: Changes in Contemporary Islamic Authority. Leiden: Brill.

Barlas, Asma. 2002. "Believing Women" in Islam: Unreading Patriarchal Interpretations of the Quran. Austin: University of Texas Press.

Berglund, Jenny. 2013. Swedish Religion Education—Objective but Marinated in Lutheran Protestantism? Temenos 49: 165-84. [CrossRef]

Berglund, Jenny. forthcoming. Islamic Religious Education in Sweden. In Islamic Religious Education across Europe. Edited by Leni Franken and Bill Gent. New York/London: Routledge.

Bøe, Marianne. 2015. Family Law in Contemporary Iran: Women's Rights Activism and Shari'a. London: I.B. Tauris.

Bøe, Marianne Hafnor. 2019. Feminisme i Islam. Oslo: Universitetsforlaget.

Bøe, Marianne Hafnor, and Anne Kalvig. 2020. Mennesker, Meninger, Makter: En Introduksjon til Religionsvitenskap. Oslo: Cappelen Damm Akademisk.

Bøe, Marianne. forthcoming. Postcolonial and Feminist Perspectives in Islamic religious Education. In Islamic Religious Education across Europe. Edited by Leni Franken and Bill Gent. New York/London: Routledge.

Buchardt, Mette, and Nanna Ramsing Enemark. forthcoming. Islamic religious education in Danish state schools. In Islamic Religious Education across Europe. Edited by Leni Franken and Bill Gent. New York/London: Routledge.

COE. 2015. Teaching Controversial Issues. Available online: https://rm.coe.int/16806948b6 (accessed on 8 December 2020).

Donner, Fred. 2010. Muhammad and the Believers: At the Origins of Islam. Cambridge: Harvard University Press.

Eidhamar, Levi. 2017. 'My Husband is My Key to Paradise'. Attitudes of Muslims in Indonesia and Norway to Spousal Roles and Wife-Beating. Islam and Christian-Muslim Relations 29: 241-64. [CrossRef]

Eidhamar, Levi. 2019. Innenfra eller utenfra, faglig eller personlig? Perspektiver i religions-og livssynsundervisningen belyst ut fra internasjonal debatt. Prismet: Religionspedagogisk Tidsskrift 70: 7-46. [CrossRef]

Eltahawy, Mona. 2015. Jomfruhinner og Hijab: Hvorfor Midtøsten Trenger en Kjønnsrevolusjon. Oslo: Gyldendal.

Fazlhashemi, Mohammad. 2019. Konstruktiv religionskritik och islam. In Konstruktiv Religionskritik: Filosofiska, Teologiska och Pedagogiska Perspektiv. Edited by Olof Franck and Mikael Stenmark. Stockholm: Sanoma Utbildning, pp. 158-98.

Franken, Leni, and Bill Gent, eds. forthcoming. Islamic Religious Education across Europe. New York/London: Routledge.

Hammer, Juliane. 2012. American Muslim Women, Religious Authority and Activism: More than a Prayer. Austin: University of Texas Press.

Härenstam, Kjell. 2009. Images of Muslims in Swedish school textbooks. In Nordic Identities in Transition: As Reflected in Pedagogic Texts and Cultural Contexts. Edited by Bente Aamotsbakken and Staffan Selander. Oslo: Novus Press, pp. 171-90.

Hidayatullah, Aysha A. 2014. Feminist Edges of the Qur'an. Oxford: Oxford University Press.

Ishaq, Bushra. 2017. Hvem Snakker for Oss? Muslimer i Dagens Norge-Hvem er de og hva Mener de? Oslo: Cappelen Damm.

Iversen, Lars Laird. 2017. Uenighetsfellesskap: kan skolen være et treningsrom for offentlig uenighet. In Religion $i$ skolen: Didaktiske Perspektiver på religions-og Livssynsfaget. Edited by Marie von der Lippe and Sissel Undheim. Oslo: Universitetsforlaget, pp. 101-16.

Iversen, Lars Laird. 2019. From Safe Spaces to Communities of Disagreement. British Journal of Religious Education 41: 315-26. [CrossRef]

Jackson, Robert. 2019. Religious Education for Plural Societies: The Selected Works of Peter Jackson. New York: Routledge. 
Joy, Morny. 2001. Postcolonial Reflections: Challenges for Religious Studies. Method E Theory in the Study of Religion 13: 177-95. [CrossRef]

Kian-Thiébaut, Azadeh. 2000. Women's Religious Seminaries in Iran. ISIM Newsletter 6: 23. Available online: https:/openaccess.leidenuniv.nl/bitstream/handle/1887/17451/ISIM_6_Women-s_Religious_ Seminariesin_Iran.pdf?sequence=1 (accessed on 8 December 2020).

Lamrabet, Asma. 2016. Women in the Quran: An Emancipatory Reading. Leicestershire: Kube Publishing Ltd.

Lincoln, Bruce. 1996. Theses on Method. Method E Theory in the Study of Religion 8: 225-27. [CrossRef]

Lövheim, Mia, Caroline Wilson, Benedetta-Selene Zorzi, and Johanna Sumiala, eds. 2017. Media, Religion and Gender in Europe, 1st ed. Barcelona: Blanquerna School of Communication and International Relations.

Mattson, Ingrid. 2005. Can a Woman be an Imam? Debating Form and Function in Muslim Women's Leadership. Ingrid Mattson.org. June 20. Available online: http://ingridmattson.org/article/can-a-woman-be-an-imam/ (accessed on 8 December 2020).

McCutcheon, Russel T. 1999. The Insider/Outsider Problem in the Study of Religion: A Reader. New York: Continuum International Publishing.

Mernissi, Fatima. 1991. The Veil and the Male Elite: A Feminist Interpretation of Women's Rights in Islam. New York: Basic Books.

Mir-Hosseini, Ziba. 2012. Decoding the DNA of Patriarchy in Muslim Family Laws. Open Democracy. Available online: https://www.opendemocracy.net/en/5050/decoding-dna-of-patriarchy-in-muslim-familylaws/ (accessed on 8 December 2020).

Niemi, Kristian. 2018. Religionsvetenskapliga tröskelbegrepp: Stötsestenar och sprängbrador vid utvecklingen av et ämnesperspektiv. Nordidactica: Journal of Humanities and Social Science Education 2: 1-22.

Otterbeck, Jonas. 2005. What is Reasonable to Demand? Islam in Swedish Textbooks. Journal of Ethnic and Migration Studies 31: 95-812. [CrossRef]

Petersen, Jesper. 2019. Media and the Female Imam. Religions 10: 159. [CrossRef]

Pew Research Center. 2012. Most Muslims Want Democracy, Personal Freedoms, and Islam in Political Life: Chapter Four. Available online: https://www.pewresearch.org/global/2012/07/10/chapter-4-gender-equality/ (accessed on 16 October 2020).

Quartermaine, Angela. 2016. Discussing Terrorism: A Pupil-inspired Guide to UK Counter-terrorism Policy Implementation in Religious Education Classrooms in England. British Journal of Religious Education 38: 13-29. [CrossRef]

Rinaldo, Rachel. 2013. Mobilizing Piety: Islam and Feminism in Indonesia. Oxford: Oxford University Press.

Rissanen, Inkeri. 2012. How Finnish Muslim Students Perceive and Deal with Religious and Cultural Difference: Negotiating Religious Tradition with Modern Liberal and Postmodern Ideals. Education Research International 2012. [CrossRef]

Sakaranaho, Tuula. 2019. The Governance of Islamic Religious Education in Finland: Promoting "General Islam" and the Unity of All Muslims. In Muslims at the Margins of Europe: Finland, Greece, Ireland and Portugal. Edited by Tuoms Martikainen, José Mapril and Adil Hussain Khan. Leiden/Boston: Brill, pp. 67-88.

Sakaranaho, Tuula, and Inkeri Rissanen. forthcoming. Islamic Religious Education in Finland. In Islamic Religious Education across Europe. Edited by Leni Franken and Bill Gent. New York/London: Routledge.

Samani, Shamim. 2016. Between Texts and Contexts: Contemporary Muslim Gender Roles. Islam and Christian-Muslim Relations 27: 319-32. [CrossRef]

Schielke, Samuli, and Liza Debevec, eds. 2012. Ordinary Lives and Grand Schemes: An Anthropology of Everyday Religion. Brooklyn: Berghahn Books.

Shaikh, Sadiyya. 2012. Sufi Narratives of Intimacy: Ibn Arabi, Gender, and Sexuality. Chapel Hill: University of North Carolina Press.

Sky, Jeanette. 2007. Kjønn og Religion. Oslo: Pax Forlag.

Synnes, Ronald M. 2019. Kjønn og religiøse grenser: Unge muslimer og kristnes forhandlinger av kjønn i migrantmenigheter. Norsk Sosiologisk Tidsskrift 4: 254-68. [CrossRef]

Toft, Audun. 2018. Inescapable News Coverage: Media Influence on Lessons About Islam. In Contesting Religion: The Media Dynamics of Cultural Conflicts in Scandinavia. Edited by Knut Lundby. Berlin/Boston: De Gruyter, pp. 259-78.

Toft, Audun. 2019. The Extreme as the Normal; Binary Teaching and Negative Identification in Religious Education Lessons about Islam. British Journal of Religious Education 42: 325-37. [CrossRef] 
Van Door-Hardner, Pieternella. 2006. Women Shaping Islam: Reading the Quran in Indonesia. Carbondale: Illinois University Press.

Von der Lippe, Marie. 2019. Teaching Controversial Issues in RE: The Case of Ritual Circumcision. British Journal of Religious Education 7: 1-11. [CrossRef]

Wadud, Amina. 1992. Quran and Woman: Rereading the Sacred Text from a Woman's Perspective. Oxford: Oxford University Press.

Wadud, Amina. 2006. Inside the Gender Jihad: Women's Reform in Islam. London: Oneworld Publications.

Publisher's Note: MDPI stays neutral with regard to jurisdictional claims in published maps and institutional affiliations.

(C) 2020 by the author. Licensee MDPI, Basel, Switzerland. This article is an open access article distributed under the terms and conditions of the Creative Commons Attribution (CC BY) license (http://creativecommons.org/licenses/by/4.0/). 